\title{
Vertical transmission and kinetic of antibodies anti-Neospora caninum in naturally infected lambs in the semiarid region of Brazil
}

\author{
Transmissão vertical e cinética de anticorpos anti-Neospora caninum em \\ cordeiros naturalmente infectados na região Semiárida do Brasil \\ Thais Ferreira Feitosa' (D); Flávia Teresa Ribeiro Costa² (D); Roberto Alves Bezerra² (D); \\ Felipe Boniedj Ventura Álvares', (1); Larissa Claudino Ferreira² (1D; Rinaldo Aparecido Mota ${ }^{3}$ (D); \\ Solange Maria Gennari4,5 (D); Hilda Fátima Jesus Pena ${ }^{4}$ (D); Sérgio Santos de Azevedo² (D); \\ Vinícius Longo Ribeiro Vilela ${ }^{1,2 *}$ (1)
}

\begin{abstract}
'Laboratório de Imunologia e Doenças Infectocontagiosas, Instituto Federal da Paraíba - IFPB, Sousa, PB, Brasil
${ }^{2}$ Programa de Pós-graduação em Ciência e Saúde Animal, Universidade Federal de Campina Grande - UFCG, Patos, PB, Brasil ${ }^{3}$ Laboratório de Doenças Infecto-contagiosas dos Animais Domésticos, Departamento de Medicina Veterinária, Universidade Federal Rural de Pernambuco - UFRPE, Recife, PE, Brasil

${ }^{4}$ Departamento de Medicina Veterinária Preventiva e Saúde Animal, Faculdade de Medicina Veterinária e Zootecnia, Universidade de São Paulo - USP, São Paulo, SP, Brasil

${ }_{5}^{5}$ Programa de Pós-graduação em Saúde Única e Bem-Estar Animal, Universidade Santo Amaro - UNISA, São Paulo, SP, Brasil
\end{abstract}

How to cite: Feitosa TF, Costa FTR, Bezerra RA, Álvares FBV, Ferreira LC, Mota RA, et al. Vertical transmission and kinetic of antibodies anti-Neospora caninum in naturally infected lambs in the semiarid region of Brazil. Braz J Vet Parasitol 2021; 30(3): e010621. https://doi.org/10.1590/S1984-29612021073

\begin{abstract}
Aimed with this study to evaluate vertical transmission of in naturally infected sheep and to monitor the kinetics of antibodies against this protozoon in their lambs. Therefore, 48 pregnant ewes, from five herds, were divided into two groups: G1 - positive for anti antibodies, with 19 animals; and G2 - seronegative, with 29 animals. Blood samples were taken from the ewes and their lambs, immediately after birth, before ingesting colostrum, and $2,7,14,21,28,35,42,49$ and 56 days after birth. Analysis on serum antibodies was performed using the indirect immunofluorescent antibody test. Among the 19 seropositive mothers, six (31.6\%) gave birth to lambs seropositive before ingesting colostrum and it was found that these lambs remained positive until the end of the study (56 days). Only one of the lambs, from a ewe that presented an antibody titer of 200 , seroconverted after ingestion of colostrum. All the lambs that had been born from negative mothers remained negative throughout the experimental period. It was concluded that transplacental transmission was an important form of diffusion of in the herds studied and that seropositive lambs maintained circulating antibodies during the period analyzed.
\end{abstract}

Keywords: IgG antibody, ovine, Transplacental infection, Neosporosis.

\section{Resumo}

Objetivou-se avaliar a ocorrência da transmissão vertical de em ovelhas naturalmente infectadas e monitorar a cinética de anticorpos para esse protozoário nos cordeiros. Portanto, foram selecionadas 48 matrizes prenhes, provenientes de cinco propriedades, e estas foram divididas em dois grupos: G1- 19 matrizes positivas para anticorpos anti- antes da prenhez; e G2 - 29 matrizes soronegativas. Foram realizadas colheitas sanguíneas nas mães e cordeiros, no G1 e G2, imediatamente após a parição, antes da ingestão do colostro. Também foi possível realizar colheitas de sangue com 2, 7, 14, 21, 28, 35, 42, 49 e 56 dias após o nascimento. A pesquisa de anticorpos séricos foi realizada por meio da Reação de Imunofluorescência Indireta (RIFI). Das 19 matrizes soropositivas, seis $(31,6 \%)$ pariram cordeiros soropositivos antes da ingestão do colostro, os quais mantiveram-se positivos até o final do experimento (56 dias). Apenas um dos cordeiros, filho de uma ovelha com título de anticorpos 200, soroconverteu após ingestão do colostro. Todos os cordeiros, filhos de mães negativas, mantiveram-se negativos

Received June 6, 2021. Accepted August 6, 2021

*Corresponding author: Vinícius Longo Ribeiro Vilela. E-mail: vinicius.vilela@ifpb.edu.br

This is an Open Access article distributed under the terms of the Creative Commons Attribution License, which permits unrestricted use distribution, and reproduction in any medium, provided the original work is properly cited. 
durante todo o período experimental. Conclui-se que a transmissão transplacentária é uma importante forma de difusão do nos rebanhos estudados e que os descendentes infectados, durante a gestação, mantiveram anticorpos circulantes durante o período analisado.

Palavras-chave: Anticorpos IgG, ovinos, infecção transplacentária, Neosporose.

\section{Introduction}

The Brazilian sheep herd consists of 18.9 million animals and, of these, 12.6 million (66.7\%) are located in the semiarid region of northeastern Brazil (IBGE, 2018). Most of the animals are raised on small farms, providing meat and milk and serving as a source of supplementary income for these families. Despite the large animal population, sheep farming in the semiarid region has low organizational and productivity levels, which reflecting the low quality of animal life and its products (Lucena et al., 2018), thus making the activity unprofitable (Aquino et al., 2016).

Among the factors that affect the productivity of the herd, reproductive efficiency is one of the most important. In Etiopia, abortion, loss of ability to ovulate and disturbances to maintaining pregnancy have been reported to be important reproductive irregularities that are capable of causing economic losses in sheep farming (Gebretensay et al., 2019). These disorders are mainly associated with infectious and parasitic diseases (Rocha et al., 2020; Dubey et al., 2017). In this context, neosporosis is an important disease that can trigger abortions and/or reproductive failures in ruminants (Arranz-Solís et al., 2015; Pereira et al., 2021).

Neospora caninum is an intracellular protozoon that is transmitted through ingestion of oocysts released into the environment by the definitive hosts (some species of domestic and wild canids), thus infecting intermediate hosts such as sheep, goats, cattle, horses and these canids themselves (Dubey et al., 2007). Another form of infection by $N$. caninum is vertical transmission, which can be exogenous or endogenous. In the exogenous form, fetal infection occurs when the mother becomes infected with the parasite during pregnancy and, in the endogenous form, when the protozoon reactivates during pregnancy, resulting from an infection prior to pregnancy (Trees \& Williams, 2005).

In sheep, the placenta is syndesmochorial, meaning that it does not allow passage of antibodies from the mother to the fetus during pregnancy. It is therefore essential that neonates should ingest colostrum to acquire protective immunoglobulins of maternal origin. However, this does not mean that the fetus is unable to produce its own antibodies during pregnancy. At 48 days of gestation, B lymphocytes are already present in lambs and can, for example, secrete immunoglobulin G (IgG) (Tizard, 2019). Consequently, it is possible to determine whether vertical transmission has occurred, by detecting pre-colostral antibodies in the serum of newborn lambs and attributing these to an immune response triggered against any pathogen that infected the mother during pregnancy.

However, numerous studies based on occurrence of antibodies against $N$. caninum have demonstrated that this parasite is present in sheep herds in all regions of Brazil, with prevalences ranging from $11.1 \%$ to $78 \%$ (Rossi et al., 2011; Correia et al., 2015; Guimarães et al., 2015; Oshiro et al., 2015; Consalter et al., 2020). In Brazil, Azevedo et al. (2017) affirmed that researches regarding evaluation vertical transmission of $N$. caninum in naturally infected sheep in herds are still scarce in Brazil and worldwide. They observed transmission rate of $15.4 \%(2 / 13)$ through pre-colostral antibodies.

Therefore, the aims of this study were to evaluate occurrences of endogenous vertical transmission of this protozoon in naturally infected sheep, through the evaluation of pre-colostral antibodies, and to monitor the antibody kinetics of their lambs, in the semiarid region of Brazil.

\section{Material and Methods}

\section{Ethics procedures}

This study was conducted at the Federal Institute of Paraíba (Instituto Federal da Paraíba, IFPB), Sousa Campus, São Gonçalo unit, with approval from the Ethics Committee on Animal Use (CEUA) of IFPB (No. 23000.001402.201864.). The owners who participated in the study signed an informed consent statement that described the procedures to be performed on the ewes and their newborns. 


\section{Study area and selection of ewes}

Five sheep-rearing farms in the semi-arid region of Paraíba were chosen. These were located in the municipalities of Sousa, Aparecida and Marizópolis (Figure 1). All of these farms had herds of at least 50 sheep of the Santa Inês or Dorper breeds and/or crossbreeds, the animals were multiparous and the owners did not mention abortion episodes. The rearing system was semi-intensive, during the daytime, these sheep grazed in areas of native Caatinga vegetation, mainly composed of mata-pasto (Senna obtusifolia L.), jurema-preta (Mimosa tenuiflora), catingueira (Caesalpinia pyramidalis), quince (Croton sonderianus), malva (Malva sp.) and favela (Cnidoscolus phyllacanthus).

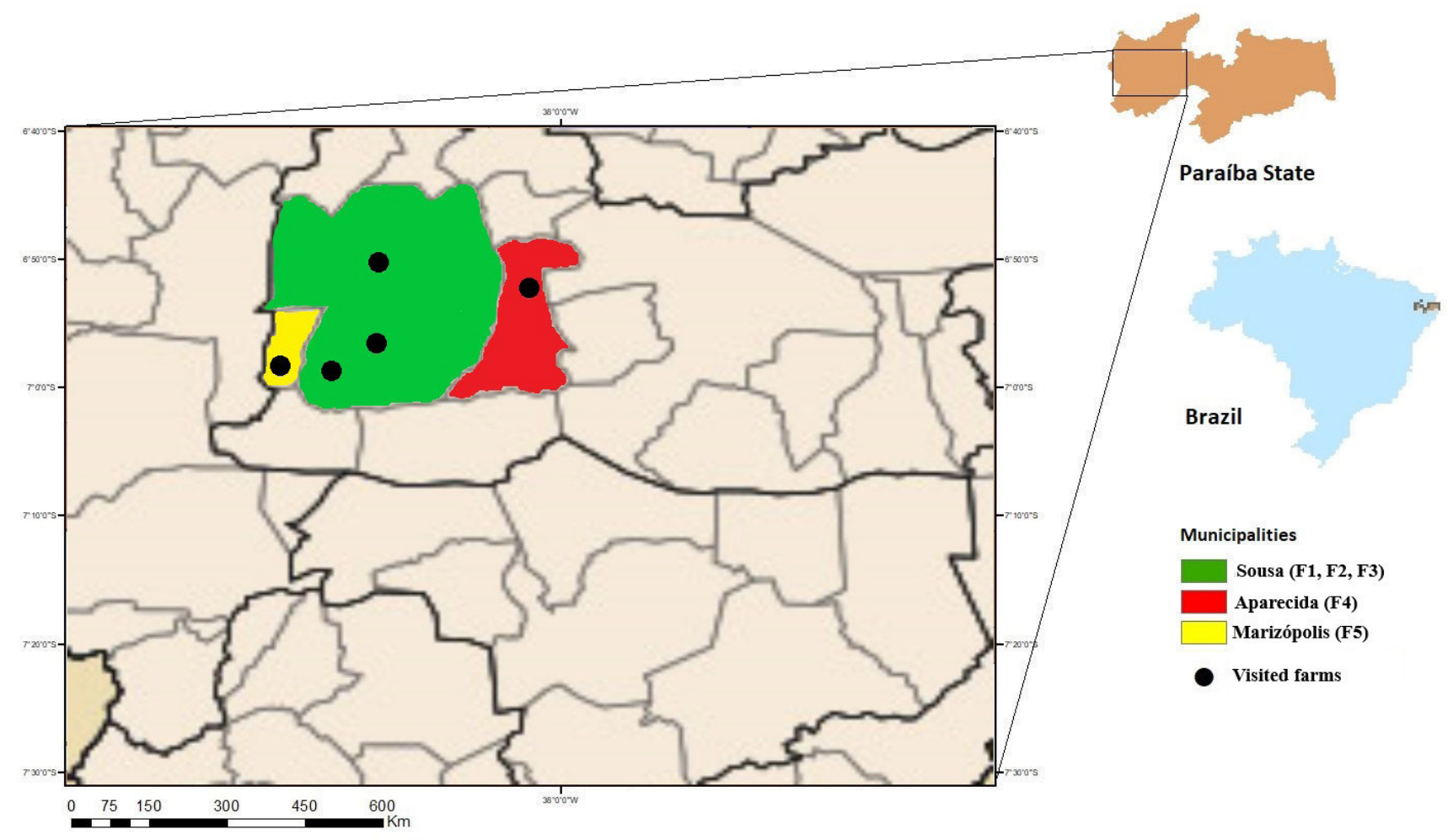

Figure 1. Geographical locations of the analyzed sheep-rearing farms in the semi-arid region of Paraíba, Brazil.

Initially, the serological status of the animals on these farms, relative to the presence of anti-N. caninum antibodies in the ewes, was ascertained by means of the indirect immunofluorescent antibody test (IFAT), in order to select ewes that were seropositive and seronegative before pregnancy. After reproduction period, the pregnancy was confirmed by ultrasonography. So, when these ewes reached the final third of their pregnancies, they were sent to the sheep-rearing sector of the IFPB. There, they were tested again for the presence of antibodies against $N$. caninum and merely animals that continued with the same serological status of the collection before pregnancy remained in this research. So, 48 sheep were selected and divided into two groups: G1, composed of 19 positive ewes; and G2, composed of 29 negative ewes. These two groups were kept in isolation, in a confinement system, in which they received voluminous food and protein-energy concentrate of soy and corn ( $0.5 \%$ live weight) in troughs, in addition to water ad libitum and mineral supplementation.

They were tested for Leptospira spp. and T. gondii using the microscopic agglutination test (MAT) and IFAT, respectively. For Leptospira spp., was performed using 24 pathogenic serogroups, in accordance with the recommendations of the World Organization for Animal Health (OIE, 2014). And for T. gondii, the IFAT test was performed with anti-lgG-sheep conjugated to fluorescein isothiocyanate (whole molecule, SIGMA, St. Louis, MO, USA), using 1:64 dilution (Camargo, 1974). In addition, they were tested for Brucella abortus through the Rose Bengal Test (RBT), as recommended by the National Program for Eradication and Control of Animal Brucellosis and Tuberculosis (PNECBT), Brazil (Brasil, 2016). Only animals negative in these tests participated in the research. 


\section{Collection of blood samples}

At birth, $5 \mathrm{~mL}$ of blood were collected by means of venipuncture of the external jugular vein, from the 48 sheep and the 60 lambs $(\mathrm{L})$ that were born from them. These blood samples were taken from the newborn lambs before colostrum intake. The sheep offspring, which owners allowed them to stay for 56 days at sheep-rearing sector of the IFPB, were selected and remained in the study. Therefore, after colostrum ingestion, 26 lambs were serologically monitored at 2, 7, 14, 21, 28, 35, 42, 49 and 56 days after birth. Among these, 13 were offspring from positive ewes (G1) and 13 were offspring from negative ewes (G2).

To obtain the pre-colostral serum (p.c.), the ewes were observed every 60 minutes, 24 hours a day, until the birth of their offspring. The blood samples were centrifuged (1,000 x g for 10 minutes) to obtain serum. This was then aliquoted, identified and kept at $-20^{\circ} \mathrm{C}$ until the time of the tests.

\section{Search for anti-N. caninum antibodies}

The serum samples were examined by means of IFAT, using anti-sheep IgG antibodies conjugated with fluorescein isothiocyanate (Sigma, St. Louis, MO, USA). The dilution that was used as the cutoff point for the ewes and their offspring after 2 days was 1:50 (Lima et al., 2008; Dubey et al., 1988). Sera that reacted at dilutions $\geq 1: 50$ (ewes and offspring after 2 days) and $\geq 1: 25$ (p. c. samples) were considered positive and then subjected to sequential two-fold serial dilutions. For the p.c. samples, the lambs were considered positive for vertical transmission when they showed anti-N. caninum antibodies $\geq 25$ (Azevedo et al., 2017).

The $N$. caninum tachyzoites used to impregnate the slides and positive and negative control sheep serum samples were provided by Laboratory of Infectious-Contagious Diseases of Domestic Animals, Federal Rural University of Pernambuco (UFRPE).

\section{Statistical analysis}

To compare the birth rates between groups $\mathrm{G} 1$ and G2, the Mann-Whitney $\mathrm{U}$ test for two independent samples was used. Fisher's exact test was used to compare the vertical transmission rates between seropositive and seronegative ewes. The different times were compared using the Friedmann test. The significance level was set at $5 \%$ and all analyzes were performed using the SPSS for Windows software, version 20.

\section{Results}

During the experiment, the ewes gave birth to 60 lambs, of which 40\% (24/60) came from 19 seropositive mothers and $60 \%$ (36/60) from 29 seronegative mothers. The average weight of lambs at birth was 2,850g for G1 and 2,905 for $G 2(P=0.230)$. The lambing rate also did not differ statistically between the groups $G 1$ and $G 2(P=0.704)$, with 1.2 and 1.3 offspring per sheep in G1 and G2, respectively.

The anti-N. caninum antibody titers among the positive ewes at the time of parturition ranged from 50 to 12,800 (Table 1).

Among the 19 sheep that were seropositive for anti-N caninum antibodies, six (31.6\%) had offspring that were reactive before ingesting colostrum. Assessment of the number of lambs born to positive mothers, taking into consideration twin births, showed that the rate of vertical transmission was $25 \%(6 / 24)$. The six positive offspring in the p.c. collection demonstrated a range of IgG titers between 50 and 3200 (Table 1), and four of them presented p.c. higher than those of their mothers. There was an association between high titers in mothers and reactive lambs before ingesting colostrum $(P=0.0005)$, i.e. the higher the antibody titer of the mother was, the higher the chance was of vertical transmission of $N$. caninum. One of the seropositive sheep (\# 9) had a twin birth and only one of the lambs was reactive before colostrum ingestion (Table 1).

All 36 lambs from negative mothers were negative in the p.c. collection, thus demonstrating that if the mother is negative, immediately before the birth, the offspring are also born seronegative $(P=0.002)$.

It was observed that all lambs positive in the p.c. which were monitored for 56 days, remained positive until at the end of the experiment $(\mathrm{L} 3, \mathrm{~L} 2, \mathrm{~L} 16, \mathrm{~L} 17)$. Excluding the six lambs congenitally infected, 1 of the $12(8,3 \%)$ lambs born from positive ewe had anti-N. caninum antibodies two days after colostrum ingestion, these lamb (L5) presented colostral antibodies, initially detected after 2 days, with a titer of 800 , and the titer decreased over the weeks, such that on day 49 this lamb was negative (titer $<50$ ). The mother of lamb L5 had a titer of 200. No other 
Table 1. Antibody titers anti-N. caninum from naturally infected sheep dams (G1) and their newborns, according to the day after birth of the lambs.

\begin{tabular}{|c|c|c|c|c|c|c|c|c|c|c|c|c|}
\hline \multicolumn{2}{|c|}{ Ewes } & \multicolumn{11}{|c|}{ Lambs Antibody Titers* (Days after the birth) } \\
\hline ID & Titers & ID & $0 * *$ & 2 & 7 & 14 & 21 & 28 & 35 & 42 & 49 & 56 \\
\hline 3 & 50 & L3 & 400 & 400 & 400 & 400 & 400 & 800 & 800 & 800 & 400 & 100 \\
\hline 17 & 50 & L17 & 3200 & 6400 & 3200 & 800 & 800 & 1600 & 1600 & 800 & 400 & 400 \\
\hline 1 & 100 & L1 & 1600 & $\mathrm{nc}$ & $\mathrm{nc}$ & $\mathrm{nc}$ & nc & $\mathrm{nc}$ & $\mathrm{nc}$ & nc & $\mathrm{nc}$ & nc \\
\hline 16 & 400 & L16 & 1600 & 3200 & 3200 & 1600 & 800 & 800 & 1600 & 800 & 200 & 100 \\
\hline \multirow[t]{2}{*}{9} & 6400 & L9 (1) & 200 & 200 & $\mathrm{nc}$ & $\mathrm{nc}$ & nc & $\mathrm{nc}$ & $\mathrm{nc}$ & $\mathrm{nc}$ & $\mathrm{nc}$ & nc \\
\hline & & L9 (2) & - & - & NC & $\mathrm{NC}$ & NC & NC & NC & NC & $N C$ & NC \\
\hline 2 & 12800 & L2 & 50 & 1600 & 800 & 800 & 800 & 800 & 800 & 400 & 200 & 100 \\
\hline 5 & 200 & L5 & $<25$ & 800 & 800 & 400 & 400 & 400 & 400 & 400 & $<50$ & $<50$ \\
\hline \multirow[t]{2}{*}{13} & 50 & L13(1) & $<25$ & $<50$ & $<50$ & $<50$ & $<50$ & $<50$ & $<50$ & $<50$ & $<50$ & $<50$ \\
\hline & & L13(2) & $<25$ & $<50$ & $<50$ & $<50$ & $<50$ & $<50$ & $<50$ & $<50$ & $<50$ & $<50$ \\
\hline 14 & 50 & L14 & $<25$ & $<50$ & $<50$ & $<50$ & $<50$ & $<50$ & $<50$ & $<50$ & $<50$ & $<50$ \\
\hline 15 & 100 & L15 & $<25$ & $<50$ & $<50$ & $<50$ & $<50$ & $<50$ & $<50$ & $<50$ & $<50$ & $<50$ \\
\hline 18 & 100 & L18 & $<25$ & $<50$ & $<50$ & $<50$ & $<50$ & $<50$ & $<50$ & $<50$ & $<50$ & $<50$ \\
\hline \multirow[t]{2}{*}{19} & 100 & L19(1) & $<25$ & $<50$ & $<50$ & $<50$ & $<50$ & $<50$ & $<50$ & $<50$ & $<50$ & $<50$ \\
\hline & & L19(2) & $<25$ & $<50$ & $<50$ & $<50$ & $<50$ & $<50$ & $<50$ & $<50$ & $<50$ & $<50$ \\
\hline \multirow[t]{2}{*}{12} & 50 & L12(1) & $<25$ & $<50$ & $<50$ & $<50$ & $<50$ & $<50$ & $<50$ & $<50$ & $<50$ & $<50$ \\
\hline & & L12(2) & $<25$ & $\mathrm{nc}$ & $\mathrm{nc}$ & $\mathrm{nc}$ & nc & $\mathrm{nc}$ & $\mathrm{nc}$ & nc & $\mathrm{nc}$ & nc \\
\hline 4 & 50 & L4 & $<25$ & $\mathrm{nc}$ & $\mathrm{nc}$ & $\mathrm{nc}$ & $\mathrm{nc}$ & $\mathrm{nc}$ & $\mathrm{nc}$ & nc & $\mathrm{nc}$ & nc \\
\hline 6 & 50 & L6 & $<25$ & $\mathrm{nc}$ & $\mathrm{nc}$ & $\mathrm{nc}$ & nc & $\mathrm{nc}$ & $\mathrm{nc}$ & nc & $\mathrm{nc}$ & nc \\
\hline \multirow[t]{2}{*}{7} & 50 & $\mathrm{~L} 7(1)$ & $<25$ & $\mathrm{nc}$ & $\mathrm{nc}$ & $\mathrm{nc}$ & nc & $\mathrm{nc}$ & $\mathrm{nc}$ & nc & $\mathrm{nc}$ & nc \\
\hline & & $\mathrm{L} 7(2)$ & $<25$ & $\mathrm{nc}$ & $\mathrm{nc}$ & $\mathrm{nc}$ & nc & $\mathrm{nc}$ & $\mathrm{nc}$ & nc & $\mathrm{nc}$ & nc \\
\hline 8 & 50 & L8 & $<25$ & $\mathrm{nc}$ & $\mathrm{nc}$ & $\mathrm{nc}$ & $\mathrm{nc}$ & $\mathrm{nc}$ & $\mathrm{nc}$ & nc & $\mathrm{nc}$ & nc \\
\hline 10 & 50 & L10 & $<25$ & $<50$ & $\mathrm{nc}$ & $\mathrm{nc}$ & $\mathrm{nc}$ & $\mathrm{nc}$ & $\mathrm{nc}$ & nc & $\mathrm{nc}$ & nc \\
\hline 11 & 50 & L11 & $<25$ & $<50$ & $\mathrm{nc}$ & $\mathrm{nc}$ & $\mathrm{nc}$ & $\mathrm{nc}$ & $\mathrm{nc}$ & nc & nc & nc \\
\hline
\end{tabular}

* Indirect immunofluorescent antibody test; **pre-colostral; ID Lamb identification. nc: not collected; <25: Lamb considered negative in precolostral collection with cut-off point $\geq 25 ;<50$ : Animal considered negative in post-colostral collections with cutoff point $\geq 50$.

lamb seroconverted after ingesting the colostrum of seropositive ewes, but all these ewes had low titers when their lambs were born, with values of 50 and 100. The lambs born to negative mothers remained negative at all the collection times.

Table 2 shows the median antibody titers of the 13 lambs born to seropositive mothers that were monitored during the 56 days of experiment. There was a statistical difference $(\mathrm{P}<0.05)$ in the median antibody titer between the lambs with and without vertical transmission, at all times. In comparing the times, significant differences were only seen between the times of $2 \mathrm{~d}$ and $56 \mathrm{~d}$, among the lambs with vertical transmission, such that the antibody titers were lower at $56 \mathrm{~d}$.

Table 2. Median and minimum and maximum titre values for anti-N. caninum antibody in lambs without vertical transmission $(n=9)$ and with vertical transmission $(n=4)$, all lambs of positive mothers, monitored throughout the experimental period.

\begin{tabular}{|c|c|c|c|c|}
\hline \multirow{2}{*}{ Time (days) } & \multicolumn{2}{|c|}{ No vertical transmission } & \multicolumn{2}{|c|}{ Vertical transmission } \\
\hline & Median** & Min; Max & Median** & Min; Max \\
\hline p.c.* & $0^{\mathrm{a}, \mathrm{A}}$ & $0 ; 0$ & $1000^{\mathrm{b}, \mathrm{A}, \mathrm{B}}$ & $50 ; 3200$ \\
\hline 2 & $0^{\mathrm{a}, \mathrm{A}}$ & $0 ; 800$ & $2400^{\mathrm{b}, \mathrm{A}}$ & $400 ; 6400$ \\
\hline 7 & $0^{\mathrm{a}, \mathrm{A}}$ & $0 ; 800$ & $2000^{\mathrm{b}, \mathrm{A}, \mathrm{B}}$ & $400 ; 3200$ \\
\hline 14 & $0^{\mathrm{a}, \mathrm{A}}$ & $0 ; 400$ & $800^{\mathrm{b}, \mathrm{A}, \mathrm{B}}$ & $400 ; 1600$ \\
\hline 21 & $0^{\mathrm{a}, \mathrm{A}}$ & $0 ; 400$ & $800^{\mathrm{b}, \mathrm{A}, \mathrm{B}}$ & $400 ; 800$ \\
\hline 28 & $0^{\mathrm{a}, \mathrm{A}}$ & $0 ; 400$ & $800^{\mathrm{b}, \mathrm{A}, \mathrm{B}}$ & $800 ; 1600$ \\
\hline 35 & $0^{\mathrm{a}, \mathrm{A}}$ & $0 ; 400$ & $1200^{\mathrm{b}, \mathrm{A}, \mathrm{B}}$ & $800 ; 1600$ \\
\hline 42 & $0^{\mathrm{a}, \mathrm{A}}$ & $0 ; 400$ & $800^{\mathrm{b}, \mathrm{A}, \mathrm{B}}$ & $400 ; 800$ \\
\hline 49 & $0^{\mathrm{a}, \mathrm{A}}$ & $0 ; 0$ & $300^{\mathrm{b}, \mathrm{A}, \mathrm{B}}$ & $200 ; 400$ \\
\hline 56 & $0^{\mathrm{a}, \mathrm{A}}$ & $0 ; 0$ & $100^{\mathrm{b}, \mathrm{B}, \mathrm{c}}$ & $100 ; 400$ \\
\hline
\end{tabular}

*pre-colostral; ${ }^{* *}$ In the same line and column, respectively, different superscript lower and upper case letters indicate a significant difference $(P<0.05)$. 


\section{Discussion}

In this study, there was no difference in lamb parturition rate between the ewes that were positive and negative for anti-N. caninum antibodies, and all the lambs were born clinically healthy. In a study carried out in the state of Pernambuco, Brazil, Azevedo et al. (2017) evaluated vertical transmission of N. caninum among naturally infected sheep and also did not observed any reproductive failures. They attributed this finding either to infection with only low levels of the parasite or to presence of a strain of low virulence that was unable to cause reproductive disorders. In contrast, González-Warleta et al. (2018), in a study carried out in Spain, observed that $7.1 \%(6 / 84)$ of ewes with recrudescence of the parasite had an abortion. Gutiérrez-Expósito et al. (2020) studied the immune response in the placenta, in sheep naturally infected with recrudescence of $N$. caninum, explaining that the severity of the lesions in the placenta and consequent damage to pregnancy depend on the gestational time when reactivation occurs. The authors also suggested that ewes whose reactivation occurred after 91 days of pregnancy could give birth to live offspring.

The rate of endogenous vertical transmission observed in the present study was $31.6 \%$, which proved to be quite efficient, with approximately one third of the chronically infected sheep giving birth to infected lambs. Studies on natural infections have shown variations in the rate of vertical transmission in chronically infected sheep from 15.4\% to 93\% (Azevedo et al., 2017; González-Warleta et al., 2018). These discrepancies can be attributed to lack of knowledge of the doses of infection to which the animals were exposed, and to the different strains and immunological conditions of the herds analyzed. However, the importance of these studies needs to be emphasized, given that they reflect the different real situations that occur on farms, in situations in which the parameters cannot be controlled.

The three ewes in $\mathrm{G} 1$ that showed titers $\geq 400$ produced offspring that were positive for $\mathrm{N}$. caninum in the p.c. The other three sheep whose offspring became infected vertically showed 50 and 100 at birth. Mesquita et al. (2013) studied the kinetics of anti-N. caninum antibodies in chronically infected goats in Brazil and found that vertical transmission only occurred when these animals had titers $\geq 200$. Arranz-Solís et al. (2015) performed experimental infection in pregnant ewes, intravenously, with 106 tachyzoites of the Nc-Spain7 strain. They observed titers ranging from 200 to 6400 in ewes from which vertical transmission occurred. It can be seen that the presence of high titers for this protozoon during pregnancy may indicate recent infection, either through reactivation of the protozoon or through exogenous infection

It was observed that the lambs that suffered vertical transmission continued to show positive serological tests up to day 56 after birth, which was the final day of the observations. Mesquita et al. (2013) found that anti-N. caninum persisted until six months of age in 8 out of 11 congenitally infected goats. In congenitally infected cattle, there is persistence of specific antibodies against $N$. caninum throughout life, whereas animals infected after birth appear to have a transient response, showing peaks with each new exposure to the parasite (Hietala \& Thurmond, 1999; Hasler et al., 2006), with increased likelihood of vertical transmission (Dubey et al., 2017).

In the present study, the antibody titers in the lambs with transplacental transmission ranged from 50 to 3200. Subsequently, these increased after colostrum intake (2 days) and then gradually decreased over the weeks after birth. The absorption of immunoglobulins through colostrum is greatest in the first six hours after birth and the peak concentration in serum levels is reached in 24 hours. After absorption, antibody levels decrease due to metabolism, since the time taken for antibody levels to reduce depends on the initial concentration (Tizard, 2019). It was observed that the lamb from ewe \# 5 of G1 was the only one among those that did not suffer vertical transmission that presented colostral antibodies, and this lamb was positive until day 42. In a study on the persistence of colostral immunity against $T$. gondii in goats, Mišurová et al. (2009) observed results similar to those of the present study, with colostral antibodies persisting until day 27-41 after birth. However, further studies with a greater number of lambs that are tested for colostral antibodies should be conducted in order to confirm the findings of this study.

Sheep \# 9 (G1) had a twin birth and only one of the offspring (L9) presented antibodies before ingesting colostrum. Two hypotheses can be raised: first, the negative neonate might in reality have been infected with $N$. caninum, but still at the beginning of the infection, with levels of antibodies not detectable through IFAT. The second hypothesis involves the physiological aspects of ruminants when they present twin pregnancy: the two uterine horns can develop in parallel, containing one or more fetuses in each horn. In this case, the two fetuses can remain isolated in two independent chorions (King \& Atkinson, 1987), thus making it possible for infection of only one chorion to occur. 


\section{Conclusion}

Endogenous vertical transmission occurs of semiarid region, and is an important route for infection by N. caninum in sheep. It gives rise to clinically healthy, but infected and potentially transmitting animals. There appears to be an association between passive transmission of maternal anti- $N$. caninum antibodies and the antibody titer of the mother, that passive transmission of maternal antibodies against this protozoon does not seem to occur as effectively when maternal antibody titers are low $(<200)$.

\section{Acknowledgements}

SMG and SSA had received a research productivity grant and TFF a postdoctoral fellowship from the National Research Council (CNPq), Brazil.

\section{References}

Aquino R, Lemos C, Alencar C, Silva E, Lima R, Gomes J, et al. A realidade da caprinocultura e ovinocultura no semiárido brasileiro: um retrato do sertão do Araripe, Pernambuco. Pubvet 2016; 10(4): 271-281. http://dx.doi.org/10.22256/pubvet.v10n4.271-281.

Arranz-Solís D, Benavides J, Regidor-Cerrillo J, Fuertes M, Ferre I, Ferreras MC, et al. Influence of the gestational stage on the clinical course, lesional development and parasite distribution in experimental ovine neosporosis. Vet Res 2015; 46(1): 19. http:// dx.doi.org/10.1186/s13567-014-0139-y. PMid:25884945.

Azevedo PCG Fo, Oliveira JMB, Andrade MR, Silva JG, Kim PCP, Almeida JC, et al. Incidence and vertical transmission rate of Neospora caninum in sheep. Comp Immunol Microbiol Infect Dis 2017; 52: 19-22. http://dx.doi.org/10.1016/j.cimid.2017.05.006. PMid:28673457.

Brasil. Ministério da Agricultura, Pecuária e Abastecimento. Instrução Normativa nº 19 de 10 de outubro de 2016. Aprova o Regulamento Técnico do Programa Nacional de controle e Erradicação da brucelose e da Tuberculose Animal - PNCEBT. Diário Oficial da República Federativa do Brasil, Brasília, 3 nov 2016, Seção 1, p. 7.

Camargo ME. Introdução às técnicas de imunofluorescência. Rev Bras Patol Clin 1974; 10: 143-169.

Consalter A, Silva AF, Gaia VG, Zanella EL, Souza GN, Ferreira AMR. Seroprevalence and risk factors associated with Neospora caninum in commercial sheep from northwest of Rio Grande do Sul, Brazil. Semina: Ciênc Agrár 2020; 41(2): 1-8. http://dx.doi. org/10.5433/1679-0359.2020v41n2p703.

Correia ELB, Feitosa TF, Santos FA, Azevedo SS, Pena HFJ, Gennari SM, et al. Prevalence and risk factors for Toxoplasma gondii in sheep in the State of Paraiba, Northeastern Brazil. Rev Bras Parasitol Vet 2015; 24(3): 383-386. http://dx.doi.org/10.1590/S198429612015043. PMid:26291143.

Dubey JP, Hattel AL, Lindsay DS, Topper MJ. Neonatal Neospora caninum infection in dogs: isolation of the causative agent and experimental transmission. J Am Vet Med Assoc 1988; 193(10): 1259-1263. PMid:3144521.

Dubey JP, Hemphill A, Calero-Bernal R, Schares G. Neosporosis in animals. Boca Raton: CRC Press; 2017. http://dx.doi. org/10.1201/9781315152561.

Dubey JP, Schares G, Ortega-Mora LM. Epidemiology and Control of Neosporosis and Neospora caninum. Clin Microbiol Rev 2007; 20(2): 323-367. http://dx.doi.org/10.1128/CMR.00031-06. PMid:17428888.

Gebretensay A, Alemayehu G, Rekik M, Alemu B, Haile A, Rischkowsky B, et al. Risk factors for reproductive disorders and major infectious causes of abortion in sheep in the highlands of Ethiopia. Small Rumin Res 2019; 177: 1-9. http://dx.doi.org/10.1016/j. smallrumres.2019.05.019.

González-Warleta M, Castro-Hermida JA, Calvo C, Pérez V, Gutiérrez-Expósito D, Regidor-Cerrillo J, et al. Endogenous transplacental transmission of Neospora caninum during successive pregnancies across three generations of naturally infected sheep. Vet Res 2018; 49(1): 106. http://dx.doi.org/10.1186/s13567-018-0601-3. PMid:30333061.

Guimarães A, Raimundo JM, Moraes LMB, Silva AT, Santos AH, Pires MS, et al. Occurrences of anti-Toxoplasma gondii and antiNeospora caninum antibodies in sheep from four districts of Tocantins state, Brazilian Legal Amazon Region. Pesq Vet Bras 2015; 35(2): 110-114. http://dx.doi.org/10.1590/S0100-736X2015000200002.

Gutiérrez-Expósito D, González-Warleta M, Espinosa J, Vallejo-García R, Castro-Hermida JA, Calvo C, et al. Maternal immune response in the placenta of sheep during recrudescence of natural congenital infection of Neospora caninum. Vet Parasitol 2020; 285: 109204. http://dx.doi.org/10.1016/j.vetpar.2020.109204. PMid:32916458.

Häsler B, Hernandez JA, Reist M, Sager H, Steiner-Moret C, Staubli D, et al. Neospora caninum: serological follow-up in dairy cows during pregnancy. Vet Parasitol 2006; 137(3-4): 222-230. http://dx.doi.org/10.1016/j.vetpar.2006.01.007. PMid:16469449. 
Hietala SK, Thurmond MC. Postnatal Neospora caninum transmission and transient serologic responses in two dairies. Int J Parasitol 1999; 29(10): 1669-1676. http://dx.doi.org/10.1016/S0020-7519(99)00102-2. PMid:10608453.

Instituto Brasileiro de Geografia e Estatística - IBGE. Produção da Pecuária Municipal [online]. Rio de Janeiro: IBGE; 2018 [cited 2021 Jun 20]. Available from: https://biblioteca.ibge.gov.br/visualizacao/periodicos/84/ppm_2018_v46_br_informativo.pdf

King GJ, Atkinson BA. The bovine intercaruncular placenta throughout gestation. Anim Reprod Sci 1987; 12(4): 241-254. http:// dx.doi.org/10.1016/0378-4320(87)90096-0.

Lima JTR, Ahid SMM, Barrêto Júnior RA, Pena HFJ, Dias RA, Gennari SM. Prevalência de anticorpos anti-Toxoplasma gondii e antiNeospora caninum em rebanhos caprinos do município de Mossoró, Rio Grande do Norte. Braz J Vet Res Anim Sci 2008; 45(2): 81-86. http://dx.doi.org/10.11606/issn.1678-4456.bjvras.2008.26703.

Lucena CC, Martins EC, Magalhães KA, Holanda ZF Fo. Produtos de origem caprina e ovina: mercado e potencialidades na região do semiárido brasileiro. Sobral: Embrapa Caprinos e Ovinos; 2018 (INFOTECA-E; no. 3).

Mesquita LP, Nogueira Cl, Costa RC, Orlando DR, Bruhn FRP, Lopes PFR, et al. Antibody kinetics in goats and conceptuses naturally infected with Neospora caninum. Vet Parasito/ 2013; 196(3-4): 327-333. http://dx.doi.org/10.1016/j.vetpar.2013.03.002. PMid:23537945.

Mišurová L, Svobodová V, Pavlata L, Dvořák R. Titres of specific antibodies against Toxoplasma gondii in goats and their kids. Acta Vet Brno 2009; 78(2): 259-266. http://dx.doi.org/10.2754/avb200978020259.

Oshiro LM, Reis FA, Dittrich RL, Cunha RC, Andreotti R. Serology for Toxoplasmosis and Neosporosis in Ewes in the State of Mato Grosso do Sul, Brazil. J Vet Sci Technol 2015; 6(4): 1000233. http://dx.doi.org/10.4172/2157-7579.1000233.

Pereira KAG, de Sousa RS, Varaschin MS, Becker APBB, Monteiro ALG, de Oliveira Koch M, et al. Transplacental transmission of Neospora caninum to lambs in successive pregnancies of naturally infected sheep in Southern Brazil. Vet Parasitol Reg Stud Reports 2021; 23: 100537. http://dx.doi.org/10.1016/j.vprsr.2021.100537. PMid:33678390.

Rocha BR, Martins G, Lilenbaum W. An historical view of the experimental leptospiral infection in ruminants. Comp Immunol Microbiol Infect Dis 2020; 73: 101532. http://dx.doi.org/10.1016/j.cimid.2020.101532. PMid:32980802.

Rossi GF, Cabral DD, Ribeiro DP, Pajuaba ACAM, Corrêa RR, Moreira RQ, et al. Evaluation of Toxoplasma gondii and Neospora caninum infections in sheep from Uberlândia, Minas Gerais State, Brazil, by different serological methods. Vet Parasitol 2011; 175(3-4): 252-259. http://dx.doi.org/10.1016/j.vetpar.2010.10.017. PMid:21075529.

Tizard IR. Imunologia veterinária. 10. ed. Rio de Janeiro: Elsevier; 2019.

Trees AJ, Williams DJL. Endogenous and exogenous transplacental infection in Neospora caninum and Toxoplasma gondii. Trends Parasitol 2005; 21(12): 558-561. http://dx.doi.org/10.1016/j.pt.2005.09.005. PMid:16223599.

World Organization for Animal Health - OIE. Leptospirosis [online]. 2014 [cited 23 Nov 2020]. Available from: https://www.oie. int/fileadmin/Home/eng/Health_standards/tahm/3.01.12_LEPTO.pdf 